\title{
CARCINOID TUMOUR WITH CYSTIC TERATOMA IN OVARY- A CASE REPORT
}

\author{
Sanjaykumar Patil1, Sonal Phadtare 2
}

1 Professor, Department of Obstetrics and Gynaecology, Krishna Institute of Medical Sciences, Karad. 2Postgraduate Student, Department of Obstetrics and Gynaecology, Krishna Institute of Medical Sciences, Karad.

\begin{tabular}{l}
\hline ABSTRACT \\
BACKGROUND \\
Primary ovarian carcinoid tumours are very rare. They arise from neuroendocrine tissue and represent less than $0.1 \%$ of all \\
ovarian tumours. Generally, carcinoid of the ovary shows a single histological type; however, some cases of primary mixed \\
carcinoid, characterised by two or more subtypes have been reported. Furthermore, over 90\% of cases are unilateral. Distant \\
metastases have been described only for subtypes with high proliferative activity.
\end{tabular}

Aims and Objectives- To present rare case of Ovarian cystic teratoma with carcinoid changes.

\section{CONCLUSION}

This case adds to rare reports in literature of a carcinoid of low malignant potential occurring in a mature cystic teratoma. The treatment for early stage ovarian carcinoid tumours confined to one ovary is surgery alone and excellent outcomes can be expected.

\section{KEYWORDS}

Carcinoid Tumour, Cystic Teratoma.

HOW TO CITE THIS ARTICLE: Patil S, Phadtare S. Carcinoid tumour with cystic teratoma in ovary- a case report. J. Evolution Med. Dent. Sci. 2017;6(22):1826-1828, DOI: 10.14260/Jemds/2017/402

\section{BACKGROUND}

Mature cystic teratomas are benign unilateral tumours, often diagnosed in young females. Teratomas are composed of tissues derived from the three germ layers; ectoderm, mesoderm and endoderm. ${ }^{1}$ The most common sites of occurrence is the ovary. ${ }^{2} \mathrm{~A}$ malignant tumour that arises in a pre-existing mature teratoma is called teratoma with malignant transformation, ${ }^{3}$ which occurs in $1-3 \%$ of all mature teratomas. ${ }^{4}$ Transformation includes thyroid carcinoma, adenocarcinoma and carcinoid tumour.5,6 Squamous cell carcinoma is the most common form of transformation. ${ }^{5}$ Carcinoid tumours are slow-growing tumours, originating from neuroendocrine cells which are classified into four categories: i) Insular; ii) Trabecular; iii) Strumal; and iv) Mucinous types.7,8 Carcinoids are most commonly found in the ileum and appendix. While mature cystic teratomas are benign tumours, carcinoid tumours of the ovary are considered to be malignant and are occasionally associated with metastases. ${ }^{7,8}$ The overall 5-year survival rate for patients with carcinoids regardless of location is 44 $56 \% .{ }^{9}$ The presence of regional and distant metastases is associated with a worsening in the prognosis. Hormone and vasoactive amine secretion from the carcinoid tumour cells cause carcinoid syndrome. Serotonin, tachykinins, prostaglandins and histamine are the main secretions of carcinoids. The secretions of these substances cause symptoms like flushing, diarrhoea, bronchial obstruction and heart failure. ${ }^{10}$ Surgery is the main treatment for carcinoid tumours and previous cases of carcinoids arising in mature

Financial or Other, Competing Interest: None.

Submission 01-02-2017, Peer Review 03-03-2017,

Acceptance 09-03-2017, Published 16-03-2017.

Corresponding Author:

Dr. Sanjaykumar Patil,

Krishna Hospital, Karad.

E-mail: dr.sonalphadtare@gmail.com

DOI: $10.14260 /$ jemds $/ 2017 / 402$ teratomas of the retroperitoneum and ovary, which were successfully treated by surgical resection have been reported in the literature.11,12

\section{Case Report}

A 56 years postmenopausal female came to Krishna Hospital, Karad, on an OPD basis with complaints of pain in abdomen since 1 month. She was second para with both full term vaginal deliveries. The patient was postmenopausal since 10 years. No significant past and family history.

On examination, patient was vitally stable. An adnexal mass was located in right iliac fossa approximately $7 \times 7 \mathrm{~cm}$ was felt which was mobile, cystic in consistency and regular margins. Cervix and vagina was healthy on per speculum examination. On per vaginal examination uterus size was normal, anteverted and cystic mass felt in right fornix.

All preoperative examinations were normal. Tumour marker CA-125: $8.3 \mathrm{U} / \mathrm{mL}$.

\section{USG Report}

Right ovarian complex lesion measuring 84 x 62 x 78 mm in size, encapsulated with nodular outline suggestive of dermoid cyst.

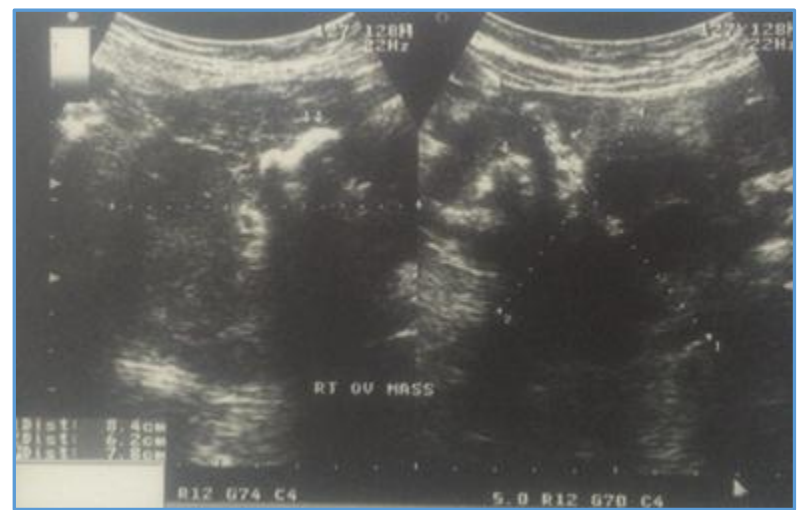

Figure 1. USG 
Patient was posted for laparotomy. Intraoperatively, uterus and left ovary appeared to be normal, while right ovary showed yellowish white surface of cystic consistency of size $79 \times 70 \times 70 \mathrm{~mm}$. Pan abdominal hysterectomy was performed and the sample sent for HPR.

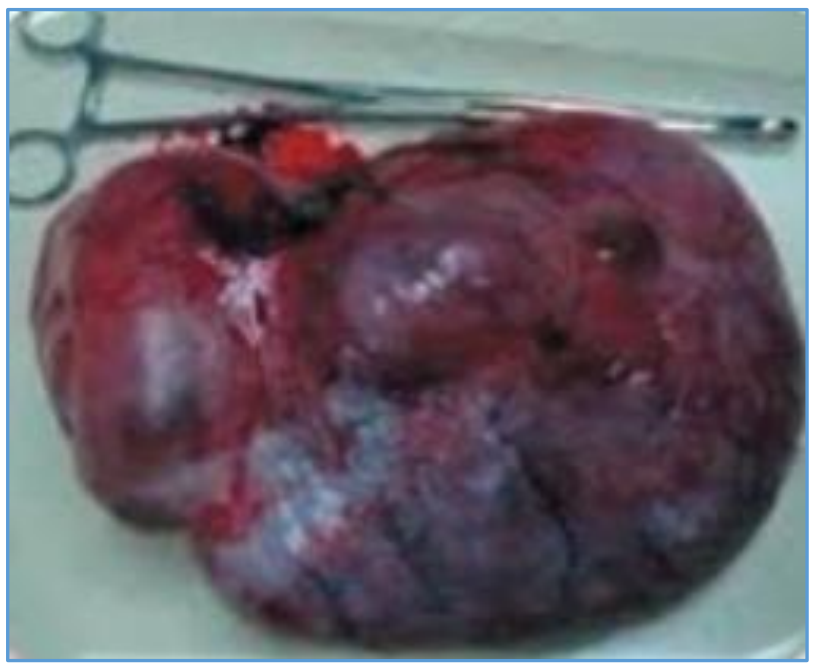

Figure 2. Specimen

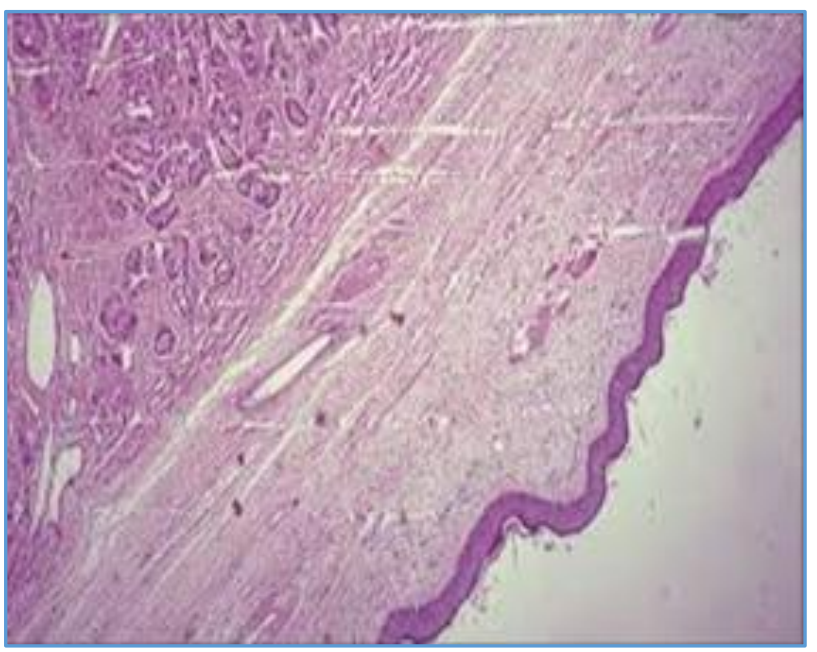

Figure 3. Histopathological Slide

The HPR showed carcinoid tumour in cystic teratoma: uniform small round cells arranged in solid masses alternating with acinar and ribbons formation separated by fibrous septae with various components like cartilage, dense fibrous and adipose tissue, smooth muscle fibres and areas of ossification.

\section{DISCUSSION}

Malignant transformation is a rare complication of mature cystic teratomas. ${ }^{13}$ Carcinoid tumours are rare and have been presented as case reports previously. ${ }^{14,15}$ Carcinoid tumours in ovarian teratomas are considered to be derived from neuroendocrine cells of the gastrointestinal or respiratory epithelium.12,16 The patient in the present report was postmenopausal. Intraoperatively, uterus and left ovary appeared to be normal, while right ovary showed yellowish white surface of cystic consistency of size 79 x 70 x $70 \mathrm{~mm}$. Pan abdominal hysterectomy was performed.
Carcinoid tumours arising in mature teratomas are tumours with low malignancy potential.12 However, the prognosis and clinical behaviour of these tumours have not yet been clarified. ${ }^{17}$

Without resection of the tumour, the risk of malignant transformation increases with time. All suspected areas in the cyst walls should be sampled in order to define these unusual rare neoplasms. In the present case report, the tumour was in a small area in the cyst wall and completely resected. This case was notable due to the rarity of this occurrence.

\section{CONCLUSION}

This case adds to rare reports in literature of a carcinoid of low malignant potential occurring in a mature cystic teratoma. The treatment for early stage ovarian carcinoid tumours confined to one ovary is surgery alone and excellent outcomes can be expected.

\section{REFERENCES}

[1] Prokhorova TA, Harkness LM, Frandsen U, et al. Teratoma formation by human embryonic stem cells is site dependent and enhanced by the presence of matrigel. Stem Cells Dev 2009;18(1):47-54.

[2] Gatcombe HG, Assikis V, Kooby D, et al. Primary retroperitoneal teratomas: a review of the literature. J Surg Oncol 2004;86(2):107-13.

[3] Harms D, Zahn S, Göbel U, et al. Pathology and molecular biology of teratomas in childhood and adolescence. Klin Padiatr 2006;218(6):296-302.

[4] Stamp GW, McConnell EM. Malignancy arising in cystic ovarian teratomas. A report of 24 cases. Br J Obstet Gynaecol 1983;90(7):671-5.

[5] Hackethal A, Brueggmann D, Bohlmann MK, et al. Squamous-cell carcinoma in mature cystic teratoma of the ovary: systematic review and analysis of published data. Lancet Oncol 2008;9(12):1173-80.

[6] Kim SM, Choi HS, Byun JS, et al. Mucinous adenocarcinoma and strumal carcinoid tumor arising in one mature cystic teratoma of the ovary with synchronous cervical cancer. J Obstet Gynaecol Res 2003;29(1):28-32.

[7] Kurman RJ, Ellenson HL, Ronnett BM. Blaustein's pathology of the female genital tract. $6^{\text {th }}$ edn. NY, New York: Springer 2011; p. 883.

[8] Robboy SJ, Mutter GL, Prat J, et al. Robboy's pathology of the female reproductive tract. $2^{\text {nd }}$ edn. London, UK: Churchill Livingstone 2009:761-5.

[9] Modlin IM, Sandor A. An analysis of 8305 cases of carcinoid tumors. Cancer 1997;79(4):813-29.

[10] Norheim I, Oberg K, Theodorsson-Norheim E, et al. Malignant carcinoid tumors. An analysis of 103 patients with regard to tumor localization, hormone production and survival. Ann Surg 1987;206(2):11525.

[11] Shindo K, Ueda J, Toubo T, et al. Primary carcinoid tumor in a retroperitoneal mature teratoma: report of a case. Surg Today 2013;43(6):694-7.

[12] Yamasaki T, Yagihashi Y, Shirahase T, et al. Primary carcinoid tumor arising in a retroperitoneal mature teratoma in an adult. Int J Urol 2004;11(10):912-5. 
[13] Donadio AC, Motzer RJ, Bajorin DF, et al. Chemotherapy for teratoma with malignant transformation. J Clin Oncol 2003;21(23):4285-91.

[14] Flam F, Silfverswärd C. Combination of granulosa cell tumour and carcinoid in an imitation of appendix vermicularis within a mature teratoma - a unique case. Eur J Obstet Gynecol Reprod Biol 1994;56(2):139-42.

[15] Chatzipantelis P, Mavrogiorgis A, Kairi-Vassilatou E, et al. Ovarian neoplasm composed of an insular carcinoid tumor and a borderline mucinous cystadenoma arising in a mature cystic teratoma: a case report. Eur J Gynaecol Oncol 2006;27(6):636-7.
[16] Sens MA, Levenson TB, Metcalf JS. A case of metastatic carcinoid arising in an ovarian teratoma. Case report with autopsy findings and review of the literature. Cancer 1982;49(12):2541-6.

[17] Isobe $\mathrm{H}$, Takashima $\mathrm{H}$, Higashi $\mathrm{N}$, et al. Primary carcinoid tumor in a horseshoe kidney. Int J Urol 2000;7(5):184-8. 